\title{
The Effectiveness of the Sizerebotif Multimedia Filter Method in Improving the Quality of Dug Well Water to be Clean Water for Communities in Sinjai Regency
}

\author{
Mulyadi Mulyadi ${ }^{* *}$, Zaenab Zaenab ${ }^{1}$, Ain Khaer $^{1}$, Adriyani Adam², Zrimurti Mappau ${ }^{3}$ \\ ${ }^{1}$ Department of Environmental Health, Health Polytechnic of Makassar, Makassar, Indonesia; ${ }^{2}$ Department of Nutrition, Health Polytechnic \\ of Makassar, Makassar, Indonesia; ${ }^{3}$ Department of Environmental Health, Health Polytechnic of Mamuju, Mamuju, Indonesia
}

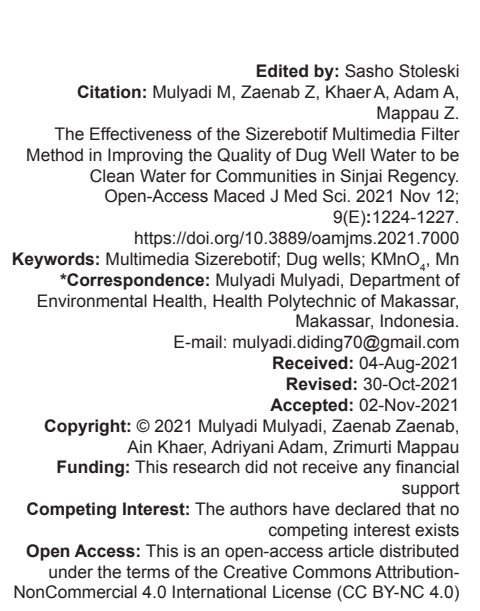

\section{Introduction}

Humans in living their lives require a variety of needs as a basis in order to live properly. One of the most important needs is the need for clean water that meets health requirements. Water is a basic requirement of every creature that lives on this earth. The need for clean water will increase as the population increases. Still not all areas can reach clean water including coastal areas inhabited by fishing communities, they are still not able to be served by a healthy water supply program. Therefore, it needs efforts from the government to accelerate access to clean water for areas that are difficult to clean water by building adequate clean water facilities and infrastructure.

One of the means of obtaining clean water which is still widely used by Indonesians is dug wells. The need for clean water is increasing day by day with the increase in population and its activities [1]. In terms of the amount (quantity) of water and soil resources, it is still relatively constant but in terms of quality, the condition is decreasing. Based on Sukamto and Supriatna, 1982, geomorphologically, Sinjai Regency is in area that has a water catchment area that stretches along the Lompobatang mountain area from the north to the south. So that, from these conditions, Sinjai Regency has a large enough potential for groundwater sources, but most of them are located in the lowlands in the form of swamps and tidal areas. Therefore, this illustrates the complexity of the aquifer [2].

The problem that is currently often encountered in the community, especially in Sinjai Regency, is the existence of several dug wells or clean water sources for the community in terms of quality which are still of concern, including the quality of dug well water that smells, tastes colored, and has sediment/limestone and a lot of it is polluted. This is certainly an inhibiting factor in efforts to meet the clean water needs of urban communities, especially Sinjai Regency. As an effort to address the provision of clean water that comes from dug wells for urban communities, there are efforts to utilize appropriate technology based on choosing the type of technology with a supporting theoretical concept, 
conformity to characteristics, availability of means of supporting materials and resources, efficiency and effectiveness. This is a form of effort that can be made and as an effort to balance the availability and dependence of clean water for urban communities to PDAM.

The physical quality of water such as smell, taste, and color is a very important indicator to pay attention to considering the condition of urban communities in meeting the demanded clean water needs quickly. Organic substances found in water come from liquid waste from activities in households, industrial areas, agricultural land, and mining activities [3]. The presence of these substances in water can be determined by measuring the parameter values $\mathrm{KMnO}_{4}$. Any deviation from the water quality standards can result in an unpleasant odor and can cause stomach upset if exposed.

The high concentration of manganese $(\mathrm{Mn})$ in water is more than $0.5 \mathrm{mg} / \mathrm{l}$ and will cause clothes that are washed to become brownish in color and can also cause damage to the liver. White objects/materials will appear stained if exposed to $\mathrm{MnO} 2$ deposits. Drinks will taste bad and smell if they contain that element. Activated carbon is one of the solutions and this media is well known by some people because of the disturbance with high levels of organic substances [4]. The use of activated carbon absorbent was chosen in this process because it has several advantages and is unique from its chemical and physical properties, namely, the ability to absorb organic and inorganic substances, acts as a cation exchanger, and as a catalyst for various reactions. Activated carbon is a kind of adsorbent, black in color, granular, round, pellet, or powder. Coconut shell is one of the active ingredients that are often used in the process of removing bad taste and odor in water, and it functions to remove organic compounds in water. Based on Mifbakhuddin (2010) [5], zeolite can be used as an adsorbent because it has a crystalline structure with a hollow silica alumina containing metal ions.

The filtration process carried out in clean water treatment aims to eliminate fine particles/flocks from the sedimentation unit, particles/flocks will be stuck in the filter media as long as the water passes through the media. Filtration activity is carried out to improve the reduction of contaminants such as Fe, odor, taste, color, and bacteria so that it will produce clean water quality that meets the requirements as drinking water [6], [7].

The basic principle of the filtration process is to filter materials/particles physically, chemically, and biologically to separate particles that pass through the sedimentation process through porous media. During the deposition process, silica elements containing impurities will be carried away. Quartz sand, also known as white sand, is derived from the weathering process of rocks that contain major minerals such as quartz and feldspar. The composition contained in quartz sand such as $\mathrm{SiO}_{2}, \mathrm{Al}_{2} \mathrm{O}_{3}, \mathrm{CaO}, \mathrm{Fe}_{2} \mathrm{O}_{3}, \mathrm{TiO}_{2}, \mathrm{CaO}, \mathrm{MgO}$, and
$\mathrm{K}_{2} \mathrm{O}$, has a clear white color or other colors depending on the impurity compound.

\section{Methods}

This study used a quasi-experimental research design by conducting water treatment trials using multimetric SiZeRC filter media against parameters of iron ( $\mathrm{Fe})$, manganese $(\mathrm{Mn})$, hardness, and organic matter (KMnO4). The experiment was done by replicating 3 times. The research location for dug well water sampling is located on Jenderal Sudirman street, Biringere Village, North Sinjai District, Sinjai Regency.

The population in this study were all dug wells in North Sinjai district. The samples were dug wells located on Jenderal Sudirman street, Biringere Village, North Sinjai District, Sinjai Regency. Balangnipa and Bongki Villages, North Sinjai East of Samataring Village, East Sinjai West side of Alehanuae Village, North Sinjai and Bongki Lengkese Village, East Sinjai, these locations were chosen based on preliminary observations tested that the quality of clean water (dug wells) from the parameters of $\mathrm{Fe}, \mathrm{Mn}$, hardness, and organic substances did not meet the equirements of clean water standards. The results of the examination of the water samples tested in Center for Environmental Health and Disease Control of Makassar then analyzed according to the Minister of Health Regulation No. 32 of 2017 concerning Clean Water [8].

\section{Results}

From well water samples taken from Jenderal Sudirman street, Biringere Village, North Sinjai District, Sinjai Regency. North of Balangnipa and Bongki Villages, North Sinjai East of Samataring Village, East Sinjai West side of Alehanuae Village, North Sinjai and Bongki Lengkese Village, East Sinjai is an area close to the shore of the bay of Bone, where the groundwater conditions smell, are brown when cooked and oily slippery, in addition to the location of groundwater near rice fields and former swamps. The lithology and environmental conditions have an influence on the quality and characteristics of the community's groundwater there.

The results of processing using this method have been carried out by pumping water into the reservoir then using a machine to drain the water from the bottom up (up flow) then flowed to the ultrafilter in the silica sand filter media then to the zeolite/ manganese ion exchange media then pine resin and finally the active carbon absorption filter media, then in 
Table 1: Results of inspection of manganese content $(\mathrm{mn})$ of dug well water before and after processing in Sinjai Regency

\begin{tabular}{|c|c|c|c|c|c|c|c|c|}
\hline \multirow[t]{3}{*}{ No. } & \multicolumn{8}{|c|}{ Manganese content $(\mathrm{Mn})$} \\
\hline & \multicolumn{2}{|c|}{ Method multimedia } & \multicolumn{2}{|c|}{ Reduction } & \multicolumn{2}{|l|}{ Control } & \multicolumn{2}{|c|}{ Reduction } \\
\hline & Pre $(\mathrm{mg} / \mathrm{l})$ & Post (mg/l) & $(\mathrm{mg} / \mathrm{l})$ & $(\%)$ & Pre $(\mathrm{mg} / \mathrm{l})$ & Post (mg/l) & $(\mathrm{mg} / \mathrm{l})$ & $(\%)$ \\
\hline 1 & 0.6019 & 0.1225 & 0.48 & 79.65 & 0.6019 & 0.6221 & -0.0202 & -3.36 \\
\hline 2 & 0.6117 & 0.1117 & 0.50 & 81.74 & 0.6117 & 0.6411 & -0.0294 & -4.81 \\
\hline 3 & 0.6038 & 0.1224 & 0.48 & 79.73 & 0.6038 & 0.6514 & -0.0476 & -7.88 \\
\hline Average & 0.61 & 0.12 & 0.49 & 80.37 & 0.61 & 0.64 & -0.03 & -5.35 \\
\hline
\end{tabular}

the final stage, it is melted into the ultra-filter cartridge. Before the laboratory examination of the water sample is carried out, the first thing is to do the processing using the Sizerebotif Multimedia tool for 3 times (replication). After 3 times replication of the sample water, the next stage is sample was taken to Center for Environmental Health and Disease Control of Makassar for examination. The laboratory test results obtained according to the results listed in the Tables 1 and 2 as follows:

Table 2: Results of inspection of organic substance levels (KMn04) dug well water before and after processing in Sinjai

\begin{tabular}{|c|c|c|c|c|c|c|c|c|}
\hline \multirow[t]{3}{*}{ No. } & \multicolumn{8}{|c|}{ Organic content $\left(\mathrm{KMnO}_{4}\right)$} \\
\hline & \multicolumn{2}{|c|}{ Method multimedia } & \multicolumn{2}{|c|}{ Reduction } & \multicolumn{2}{|l|}{ Control } & \multicolumn{2}{|c|}{ Reduction } \\
\hline & Pre $(\mathrm{mg} / \mathrm{l})$ & Post (mg/l) & $(\mathrm{mg} / \mathrm{l})$ & (\%) & Pre $(\mathrm{mg} / \mathrm{l})$ & Post (mg/l) & $(\mathrm{mg} / \mathrm{l})$ & $(\%)$ \\
\hline 1 & 24.76 & 7.48 & 17.28 & 69.79 & 24.76 & 17.88 & 6.88 & 27.79 \\
\hline 2 & 24.88 & 7.44 & 17.44 & 70.10 & 24.88 & 17.10 & 7.78 & 31.27 \\
\hline 3 & 24.82 & 7.4 & 17.42 & 70.19 & 24.82 & 17.12 & 7.70 & 31.02 \\
\hline Average & 24.82 & 7.44 & 17.38 & 70.02 & 24.82 & 17.37 & 7.45 & 30.03 \\
\hline
\end{tabular}

\section{Discussion}

This research uses a filtration method, namely, multimedia filter combined with a filter media from shell sand, manganese greensand, and activated carbon, the use of more than 1 filter media aims to ensure that the sample water from the processing results is able to meet the standard requirements of clean water quality standards. Variations in the combination of the filter media were carried out to obtain results on the efficiency level of the filter media combination for well water treatment. The process flows of water treatment with this multimedia method in all layers functions as a filter or filter.

Manganese (Mn) is a Group VII metal element, has an atomic weight of 54.93, and has a melting point of $1247^{\circ} \mathrm{C}$ and a boiling point of $2032^{\circ} \mathrm{C}$. Manganese exists in nature not as an element but mostly as a compound with various valences. If manganese exists in nature in relation to water quality, manganese compounds are more commonly found at valences 2, 4, and valence 6 [9]. Discovery of a concentration of manganese in drinks/water exceeding $0.5 \mathrm{mg} / \mathrm{l}$ will cause anomalies in the taste and can give brownish stains to clothes that are washed, and this manganese element can also cause damage to the liver. The principle, processing manganese is the same as processing iron content. Based on the combination of ultra-filter media arrangement of silica manganese greensand sand pine resin-activated carbon ultra-filter, it is able to significantly reduce the concentration of organic substances from $24.82 \mathrm{mg} / \mathrm{L}$ to $7.44 \mathrm{mg} / \mathrm{L}$ with a reduction efficiency of $70,20 \%$. Based on the combination of ultra-filter media arrangement of silica manganese greensand sand pine resin-activated carbon ultra-filter, it is able to significantly reduce the concentration of organic substances from $24.82 \mathrm{mg} / \mathrm{L}$ to $7.44 \mathrm{mg} / \mathrm{L}$ with a reduction efficiency of $70,20 \%$, because the sample water that passes through the shell sand media will be filtered or stuck in the pores of the silica sand media which have an effective size of 2 $\mathrm{mm}$, where the mechanisms that occur are mechanical straining, sedimentation, and interception. Then, the water will pass through the manganese greensand media, where this media has a greater effective media than the clam sand media, this is what causes the interception mechanism, where organic substances $\left(\mathrm{KMnO}_{4}\right)$ immediately move toward and will hit the filter media, causing the organic substances to be suspended adhering on the filter media and sedimentation occurs in the filter media.

The next step after that is the sample water will pass through the activated carbon media. This condition is quite good, because the activated carbon media will be more optimal in removing organic substances. This is in line with Fajarwati's research [10] the results of the researchers stated that the thicker the filter media will cause the quantity of filters used to increase so that the filtering ability will be better. In addition, activated carbon is also a medium that has good adsorption properties so that its position as the final filter media can help the process of removing organic substances. The increase in the quantity of activated carbon causes an increase in the adsorption capacity of activated carbon media in reducing organic substances [11].

The use of ultra-filters, silica sand in the early stages is able to reduce some dissolved minerals, then, the zeolite/manganese media stage and pine resin greatly contribute as an ion exchange in dug well water and in the final stage through carbon and ultra-filter media, it will absorb organic and residual hardness, which is still dissolved, this combination of several media gives good results when compared to several previous studies which were only carried out using separate media.

\section{Conclusion}

There was a decrease in manganese (Mn) levels after a study using this Sizerebotif multimedia filter method in dug well water was $0.5 \mathrm{mg} / \mathrm{l}$, where the average initial manganese content was $0.61 \mathrm{mg} / \mathrm{l}$ with average value after processing of $0.12 \mathrm{mg} / \mathrm{l}$ with average decrease of $0.49 \mathrm{mg} / \mathrm{l}$ or decrease of $80.37 \%$. 
For the control of manganese levels after processing, it was $0.64 \mathrm{mg} / \mathrm{l}$ with a decrease or increase of $-0.03 \mathrm{mg}$ so the percentage was $-5.35 \%$. Decreasing levels of manganese $(\mathrm{Mn})$ in well water after going through the multimedia filter process above show that the manganese content has met the standard requirements of the Minister of Health Regulation No. 32 of 2017.

The decrease in organic matter $\left(\mathrm{KMnO}_{4}\right)$ in well water obtained average initial content value of $24.82 \mathrm{mg} / \mathrm{l}$ with average level after processing of $7.44 \mathrm{mg} / \mathrm{l}$ with average decrease of $17.38 \mathrm{mg} / \mathrm{l}$ or with decrease percentage of $70.02 \%$. As for the control, the levels of organic substances decreased to $17.37 \mathrm{mg} / \mathrm{l}$ with decrease in the rate of $7.45 \mathrm{mg} / \mathrm{l}$ or decrease of $30.03 \%$.

\section{References}

1. Budiyono SS. Water Treatment Engineering. Yogyakarta: Graha Science; 2013.

2. Susilawati S. Shallow Groundwater Aquifer System Makassar City, South Sulawesi Province. Indonesia: Hasanuddin Univesity; 2009.

3. Gumelar D, Hendrawan $\mathrm{Y}$, Yulianingsih R. Pengaruh aktivator dan waktu kontak terhadap kinerja arang aktif berbahan eceng gondok (Eichornia crossipes) pada penurunan COD limbah cair laundry. J Keteknikan Pertanian Trop Biosistem. 2014;3(1):1523. Available from: https://www.jkptb.ub.ac.id/index.php/jkptb/ article/view/242 [Last accessed on 2021 May 17].

4. Sebayang P. Dirty and Brackish Water Treatment Technology to Become Clean and Drinkable Water. Jakarta, Indonesia: LIPI Press; 2015

5. Mifbakhuddin. The effect of thickness of activated carbon as a filter media on decreasing artistic well ater hardness. J Explan. 2010;5(2).

6. Asmadi K, Khayan HS. Drinking Water Treatment Technology. Yogyakarta: Gosyen Publishing; 2011.

7. Luthfiah VA. Differences in the effectiveness of up flow and down flow filtration systems using shellfish media and activated carbon in reducing iron ( $\mathrm{Fe}$ ) content in dug well water at star borneo residence 7 housing. Sanitarian. 2015;7(2):158-64.

8. Ministry of Health I. Permenkes No. 32 Concering Environmental Health Quality standards and Water Health Requirements for Sanitation Hygiene Needs, swimming Pools, Solus Per Aqua and Public Baths. Jakarta, Indonesia; 2017.

9. Iwao T. Water Work Engineering (JOSUI KOGAKU). Japanese Edition, Tokyo; 1971

10. Fajarwati I. Groundwater Treatment with Multifiltration System Using Shell Shells, Zeolite and Activated Carbon. Faculty of Engineering. West Kalimantan: Tanjung Pura University; 2014.

11. Pradana TD. Effectiveness of lime powder coagulant and filtration with up flow and down flow methods to reduce Fe. J Public Health Khatulistiwa JKMK. 2018;5(1):32-41. 